\title{
PENGARUH PEMBERIAN SARI KACANG HIJAU (Vigna Radiata) TERHADAP KADAR HEMOGLOBIN IBU HAMIL ANEMIA
}

\author{
THE EFFECT OF GIVING GREEN NUTS (Vigna Radiata) TO THE LEVELS OF HEMOGLOBIN PREGNANT ANEMIA \\ MOM
}

\author{
Vina Aulia*);Sunarto;Arintina Rahayuni
}

\begin{abstract}
Background : Based on the results of Basic Health Research (Riskesdas) in 2013, the prevalence of anemia in pregnant women in Indonesia is 37,1\%. The incidence of anemia in Central Java in 2015 reached 56,2\% which is higher than the national rate of 50,5\%. The incidence of anemia in pregnant women will increase the risk of maternal death. To reduce the incidence of anemia in pregnant women is done by consuming at least $90 \mathrm{Fe}$ tablets, but must be supported and assisted by providing intake of foods rich in iron. One type of peanuts that contain high in iron is mungbean. Mungbean contain the substances needed for the formation of blood cells that can overcome the effects of decreased hemoglobin.
\end{abstract}

Objective : To know the effect of mungbeans juice on hemoglobin levels of anemia pregnant women.

Method : This study used the Pretest-Posttest Control GroupDesign. Number of samples each group of 10 people interventions performed on the treatment group in the form of mungbeans juice for 20 days in anemia pregnant women who consumed Fe tablets while control group only consumed Fe tablets. Test used to know the effect of intervention on hemoglobin level using ANOVA Repeated Measure with $\alpha=0,05$.

Result : The mean elevation of hemoglobin level after intervention in the treatment group was $0,84 \mathrm{~g} / \mathrm{dl}$ and in the control group $0,71 \mathrm{~g} / \mathrm{dl}$. Based on the results of anova test, there was no significant effect $(p=0,452)$ of mungbeans juice on hemoglobin levels of anemia pregnant women after controlled with energy, protein, iron, vitamin C and vitamin A intake.

Conclusion : There was no significant effect of mungbean juice on hemoglobin levels of anemia pregnant women.

Keywords : mungbean juice, anemia pregnant women, hemoglobin levels

\section{ABSTRAK}

Latar Belakang : Berdasarkan hasil Riset Kesehatan Dasar (Riskesdas) tahun 2013, prevalensi anemia pada ibu hamil di Indonesia sebanyak 37,1\%. Angka kejadian anemia di Jawa Tengah pada tahun 2015 mencapai 56,2\% yang lebih tinggi dari angka nasional yaitu 50,5\%. Kejadian anemia pada ibu hamil akan meningkatkan risiko terjadinya kematian ibu. Untuk menurunkan angka kejadian anemia pada ibu hamil dilakukan dengan mengkonsumsi minimal 90 tablet Fe, tetapi harus ditunjang dan dibantu dengan memberikan asupan makanan yang kaya akan zat besi.Salah satu jenis kacang-kacangan yang mengandung zat besi tinggi adalah kacang hijau.Kacang hijau mengandung zat-zat yang diperlukan untuk pembentukan sel darah sehingga dapat mengatasi efek penurunan hemoglobin.

Tujuan: Untuk mengetahui pengaruh pemberian sari kacang hijauterhadapkadar hemoglobin ibu hamil anemia.

Metode: Penelitian ini menggunakanrancangan Pretest-Posttest Control GroupDesign. Jumlah sampel masingmasing kelompok sebanyak 10 orang. Intervensi yang dilakukan pada kelompok perlakuan berupa pemberian sari kacang hijau selama 20 hari pada ibu hamil anemia yang mengkonsumsi tablet Fe, sedangkan kelompok kontrol hanya mengkonsumsi tablet Fe. Uji yang digunakan untuk mengetahui pengaruh intervensi pada kadar hemoglobin menggunakan ANOVARepeated Measure dengan $\alpha=0,05$.

Hasil: Rerata peningkatan kadar hemoglobin setelah intervensi pada kelompok perlakuan sebesar $0.84 \mathrm{~g} / \mathrm{dl}$ dan pada kelompok kontrol sebesar 0,71 g/dl. Berdasarkan hasil uji anova terdapat pengaruh yang tidak signifikan $(p=0,452)$ pemberian sari kacang hijau terhadap kadar hemoglobin ibu hamil anemia setelah dikontrol dengan asupan energi, protein, zat besi, vitamin $\mathrm{C}$ dan vitamin $\mathrm{A}$. 
Kesimpulan:Terdapat pengaruh yang tidak signifikan pemberian sari kacang hijau terhadap kadar hemoglobin ibu hamil anemia.

Kata Kunci : sari kacang hijau, ibu hamil anemia, kadar hemoglobin

\section{PENDAHULUAN}

Salah satu indikator keberhasilan pembangunan dalam bidang kesehatan dapat dilihat dari tinggi rendahnya angka kematian ibu dan bayi ${ }^{1}$. Di negara berkembang, anemia pada kehamilan merupakan penyebab utama morbiditas dan mortalitas ibu dan janin ${ }^{2}$. Anemia selama kehamilan berkontribusi pada $20 \%$ kematian maternal ${ }^{3}$.

Berdasarkan hasil Riset Kesehatan Dasar (Riskesdas) tahun 2013, prevalensi anemia pada ibu hamil di Indonesia sebesar $37,1 \%{ }^{4}$. Angka kejadian anemia di Jawa Tengah pada tahun 2015 mencapai $56,2 \%$ lebih tinggi dari angka nasional yaitu 50,5\% ${ }^{5}$. Data Dinas Kesehatan Kabupaten Semarang 2015 menunjukkan jumlah ibu hamil di Kabupaten Semarang yang mengalami anemia sebanyak $20,79 \%{ }^{6}$. Hasil studi pendahuluan yang dilakukan di Puskesmas Lerep pada bulan Februari 2017 menunjukkan 58 ibu hamil anemia sebanyak $21,88 \%{ }^{7}$. Prevalensi tersebut masih lebih tinggi dari Data Dinas Kesehatan Kabupaten Semarang tahun 2015.

Anemia pada ibu hamil disebut "potensial danger to mother and child" (potensial membahayakan ibu dan anak). Anemia memerlukan perhatian serius dari semua pihak yang terkait dalam pelayanan kesehatan ${ }^{8}$. Anemia memiliki konsekuensi kesehatan yang merugikan secara signifikan, serta dampak buruk pada pembangunan sosial dan ekonomi.

Anemia dalam kehamilan adalah kondisi ibu dengan kadar hemoglobin dibawah $11 \mathrm{~g} \%$. Menurut Departemen Kesehatan RI (2009) batas normal kadar hemoglobin untuk ibu hamil $\geq 11$ $\mathrm{g} / \mathrm{dl}^{9}$. Hemoglobin adalah protein berfigmen merah yang terdapat dalam sel darah merah yang berfungsi mengangkut oksigen dari paru-paru yang akan didistribusikan keseluruh tubuh ${ }^{10}$. Pembentukan hemoglobin dibantu dengan protein, zat besi (Fe) dan vitamin C.

Pengobatan dan pencegahan untuk anemia selalu diberikan suplementasi tablet besi dan diikuti dengan mengkonsumsi makanan yang kaya akan zat besi ${ }^{11}$. Pemerintah sudah berupaya untuk mengurangi kejadian anemia ibu hamil dengan cara memberikan suplementasi tablet besi sebanyak 90 tablet pada ibu hamil, namun ternyata angka anemia ibu hamil masih saja tinggi. Hal ini bisa disebabkan karena tidak patuhnya ibu hamil dalam mengkonsumsi tablet besi. Ketidakpatuhan ini akibat dari efek samping tablet besi berupa pengaruh yang tidak menyenangkan seperti rasa tidak enak di ulu hati, mual, muntah, dan diare (terkadang juga konstipasi). Sehingga perlu diikuti dengan mengkonsumsi makanan yang kaya akan zat besi.

Salah satu jenis kacang-kacangan yang mengandung zat besi tinggi adalah kacang hijau (vigna radiata). Kacang hijau mengandung zat-zat yang diperlukan untuk pembentukan sel darah sehingga dapat mengatasi efek penurunan $\mathrm{Hb}$. Jumlah kandungan zat besi pada kacang hijau sebanyak 6,7 mg per 100 gram kacang hijau ${ }^{12}$. Kacang hijau juga mengandung fitat sebesar 2,19\%. Interaksi fitat dengan protein dan vitamin menyebabkan terbatasnya nilai gizi yang dapat dimanfaatkan tubuh. Efek negatif dari fitat bisa dikurangi dengan cara merendam kacang hijau.

Tujuan penelitian ini adalah untuk mengetahui pengaruh sari kacang hijau (Vigna Radiata) terhadap kadar hemoglobin ibu hamil yang mengalami anemia.

\section{METODE}

Penelitian ini termasuk dalam jenis penelitian eksperimen sungguhan (True Eksperimen) dengan rancangan Pretest-Posttest Control Group Design. Penelitiandilakukan di wilayah kerja Puskesmas Lerep Kecamatan Ungaran Barat, Kabupaten Semarang dengan populasi ibu hamil anemia pada bulan Januari-Maret 2018 sebanyak 44 orang dan dilakukan selama 20 hari. Subjek dalam penelitian ini adalah Ibu hamil dengan kadar $\mathrm{Hb}<11 \mathrm{~g} / \mathrm{dl}$, Ibu hamil yang mengkonsumsi suplemen tablet Fe, Ibu hamil yang tinggal menetap di wilayah kerja Puskesmas Lerep, Kabupaten Semarang. Perhitungan menggunakan randomized control trial. Jumlah seluruh subjek penelitian yaitu 20 orang dengan masing-masing 10 orang pada tiap kelompok.

Kelompok perlakuan dan kontrol diawali dengan pengecekan kadar $\mathrm{Hb}$ (pretest), kemudian pada kelompok perlakuan akan diberikan sari kacang hijau (Vigna Radiata) sedangkan kelompok kontrol tidak diberikan sari kacang hijau. Setelah pemberian treatment diadakan pengecekan kadar $\mathrm{Hb}$ kembali (posttest). Variabel Independent yaitu pemberian sari kacang hijau (Vigna Radiata), 
Variabel Dependent yaitu perubahan kadar hemoglobin ibu hamil anemia.

Instrumen yang digunakan terdiri dari formulir identitas umum responden, formulirkadar Hbsebelum dan sesudah diberikan treatment dan formulir recall 2x24 jam. Identitas umum responden diperoleh melalui wawancara dengan menggunakan formulir kuesioner. Data Kadar Hbdengan menggunakan metode Autoanalyzer yang dinyatakan dalam satuan g/dl.Data Asupan Zat Gizidiperoleh menggunakan metode recall 2x24 jam dilakukan di awal penelitian.

Analisis deskriptif digunakan untuk mendeskripsikan karakteristik setiap sampel dan karakteristik masing-masing variabel yang diteliti. Variabel yang berbentuk kategorik (Karakteristik responden meliputi usia, pekerjaan, pendidikan, usia kehamilan) disajikan dalam bentuk tabel distribusi frekuensi. Variabel yang berbentuk numerik (kadar hemoglobin kelompok kontrol dan perlakuan sebelum dan sesudah diberikan perlakuan) disajikan dalam bentuk mean, standar deviasi, dan nilai minimum-maksimum.Analisis analitik digunakan untuk menganalisis perbedaan kadar hb antara awal, akhir, kelompok kontrol dan kelompok perlakuan digunakan uji ANOVA Repeated Measure dengan Ha diterima jika $p<0,05$.

\section{HASIL PENELITIAN}

Penelitian ini dilakukan diwilayah kerja Puskesmas Lerep, Kabupaten Semarang. Puskesmas Lerep merupakan puskesmas rawat inap yang terletak di Jalan Yudistira Raya KM 3, Lerep, Ungaran Barat, Semarang, Jawa Tengah, 50519. Puskesmas Lerep memeiliki wilayah kerja yang terdiri dari 6 desa, yaitu Branjang, Kalisidi, Lerep, Keji, Bandarjo dan Nyatnyono.

\section{Karakteristik Responden}

Responden penelitian dalam penelitian ini sebanyak 20 ibu hamil anemia di wilayah kerja Puskesmas Lerep yang memenuhi kriteria inklusi untuk dijadikan sampel, terdiri dari 10 ibu hamil anemia pada kelompok perlakuan dan 10 ibu hamil anemia pada kelompok kontrol. Karakteristik responden penelitian ditampilkan pada tabel 1.

Tabel 1. Karakteristik Responden berdasarkan Usia Ibu, Pendidikan Terakhir, Pekerjaan, dan Usia Kehamilan di Wilayah Kerja Puskesmas Lerep Kabupaten Semarang pada April 2018

\begin{tabular}{|c|c|c|c|}
\hline $\begin{array}{l}\text { Karakteristik } \\
\text { Responden }\end{array}$ & $\begin{array}{l}\text { Kelompok } \\
\text { Perlakuan } \\
(n=10)\end{array}$ & $\begin{array}{c}\text { Kelompok } \\
\text { Kontrol } \\
(n=10)\end{array}$ & Total \\
\hline \multicolumn{4}{|l|}{ Usia Ibu } \\
\hline$<20$ tahun & $1(10,0 \%)$ & $0(0 \%)$ & $1(5,0 \%)$ \\
\hline $20-35$ tahun & $8(80,0 \%)$ & $1(100,0 \%)$ & $18(90,0 \%)$ \\
\hline$>35$ tahun & $1(10,0 \%)$ & $0(0 \%)$ & $1(5,0 \%)$ \\
\hline \multicolumn{4}{|l|}{ Pendidikan } \\
\hline SMP & $4(40,0 \%)$ & $1(10,0 \%)$ & $5(25,0 \%)$ \\
\hline SMA & $6(60,0 \%)$ & $9(90,0 \%)$ & $15(75,0 \%)$ \\
\hline \multicolumn{4}{|l|}{ Pekerjaan } \\
\hline Bekerja & $2(20,0 \%)$ & $7(70,0 \%)$ & $9(45,0 \%)$ \\
\hline Tidak Bekerja & $8(80,0 \%)$ & $3(30,0 \%)$ & $11(55,0 \%)$ \\
\hline \multicolumn{4}{|l|}{ Usia } \\
\hline \multicolumn{4}{|l|}{ Kehamilan } \\
\hline$\leq 12$ minggu & $0(0 \%)$ & $2(20,0 \%)$ & $2(10,0 \%)$ \\
\hline 13-24 minggu & $6(60,0 \%)$ & $7(70,0 \%)$ & $13(65,0 \%)$ \\
\hline$\geq 25$ minggu & $4(40,0 \%)$ & $1(10,0 \%)$ & $5(25,0 \%)$ \\
\hline
\end{tabular}

\section{Gambaran Asupan Zat Gizi}

Gambaran asupan zat gizi dalam penelitian ini untuk melihat rerata asupan zat gizi makro dan mikro yang meliputi energi, protein, zat besi, vitamin $C$ dan vitamin $A$ yang dikonsumsi oleh responden Ibu hamil anemia pada kelompok perlakuan dan kelompok kontrol, yang dikumpulkan melalui metode recall 2 x 24 jam diawal penelitian dengan cara wawancara, menanyakan frekuensi dan jenis makanannya termasuk asupan suplemen tablet fe dalam ukuran rumah tangga (URT) yang kemudian dianalisis dengan menggunakan nutrisurvey.

Tabel 2. Rerata Asupan Zat Gizi meliputi Energi, Protein, Zat Besi, Vitamin C dan Vitamin A pada kedua kelompok perlakuan Ibu Hamil Anemia di Wilayah Kerja Puskesmas Lerep Kabupaten Semarang pada April 2018

\begin{tabular}{lcccc}
\hline Rerata & \multicolumn{2}{c}{ Kelompok Perlakuan } & \multicolumn{2}{c}{ Kelompok Kontrol (n } \\
Asupan & \multicolumn{2}{c}{$(\mathrm{n}=10)$} & \multicolumn{2}{c}{ 10) } \\
\cline { 2 - 5 } Zat Gizi & Mean & Range & Mean & Range \\
\hline Energi & $1946 \pm$ & $1613-$ & $1816 \pm$ & $1332-$ \\
& 267 & 2626 & 295 & 2337 \\
Protein & $62,6 \pm$ & $53,7-$ & $56,0 \pm$ & $40,7-$ \\
& 10,5 & 91,6 & 11,5 & 76,1 \\
Zat & $70,6 \pm$ & $67,5-$ & $69,8 \pm$ & $66,2-$ \\
Besi & 2,3 & 74,1 & 2,1 & 73,3 \\
Vitamin & $128,4 \pm$ & $64,3-$ & $113,8 \pm$ & $61,9-$ \\
C & 67,9 & 252,7 & 49,2 & 237,1 \\
Vitamin & $1138,4 \pm$ & $826,4-$ & $1217,6 \pm$ & $698,5-$ \\
A & 323,5 & 1780,4 & 456,3 & 2037,7 \\
\hline
\end{tabular}

3. Kadar Hemoglobin Sebelum (Pretest) Dan Setelah Perlakuan (Posttest)

Pengukuran kadar hemoglobin sebanyak 2 kali selama penelitian yaitu hari ke- 
0 sebelum diberi perlakuan dan hari ke-21 setelah diberi perlakuan dengan menggunakan metode Autoanalyzer yang dinyatakan dalam satuan $\mathrm{g} / \mathrm{dl}$. Berikut adalah rerata kadar hemoglobin ibu hamil anemia sebelum dan sesudah diberi perlakuan:

Tabel 3.Rerata Kadar Hemoglobin Pada Kedua Kelompok Ibu Hamil Anemia Sebelum (pretest) dan Setelah diberi perlakuan (posttest) di Wilayah Kerja Puskesmas Lerep Kabupaten Semarang pada April 2018

\begin{tabular}{|c|c|c|c|c|c|}
\hline \multirow{2}{*}{ Kel. } & \multicolumn{2}{|c|}{ Kadar $\mathrm{Hb}$ Pre } & \multicolumn{2}{|c|}{ Kadar Hb Post } & \multirow{2}{*}{$\begin{array}{c}\text { Peningkata } \\
\text { n } \\
\text { Mean }\end{array}$} \\
\hline & $\begin{array}{c}\text { Mean } \\
\pm \text { SD }\end{array}$ & $\begin{array}{c}\text { Rang } \\
\mathrm{e}\end{array}$ & $\begin{array}{c}\text { Mean } \\
\pm S D\end{array}$ & $\begin{array}{c}\text { Rang } \\
\mathrm{e}\end{array}$ & \\
\hline $\begin{array}{l}\text { Perlak } \\
\text { uan } \\
(n=10)\end{array}$ & $\begin{array}{c}10,22 \\
\pm \\
0,56\end{array}$ & $\begin{array}{l}9,2- \\
10,8\end{array}$ & $\begin{array}{r}11,04 \\
\pm 0,58\end{array}$ & $\begin{array}{c}10,1- \\
11,7\end{array}$ & 0,84 \\
\hline $\begin{array}{l}\text { Kontrol } \\
(n=10)\end{array}$ & $\begin{array}{c}10,01 \\
\pm \\
0,48\end{array}$ & $\begin{array}{l}9,1- \\
10,6\end{array}$ & $\begin{array}{r}10,72 \\
\pm 0,50\end{array}$ & $\begin{array}{l}9,8- \\
11,3\end{array}$ & 0,71 \\
\hline
\end{tabular}

4. Pengaruh Pemberian Sari Kacang Hijau Terhadap Kadar Hemoglobin Ibu Hamil Anemia

Analisis pengaruh pemberian sari kacang hijau terhadap kadar hemoglobin Ibu Hamil anemia dilakukan dengan menggunakan uji ANOVA repeated measure. Sehingga dapat diketahui besarnya kenaikan kadar hemoglobin setelah diberi sari kacang hijau dengan variabel kontrol gambaran asupan zat gizi meliputi energi, protein, zat besi, vitamin $C$ dan vitamin A serta pengaruh pemberian sari kacang hijau terhadap kadar hemoglobin.

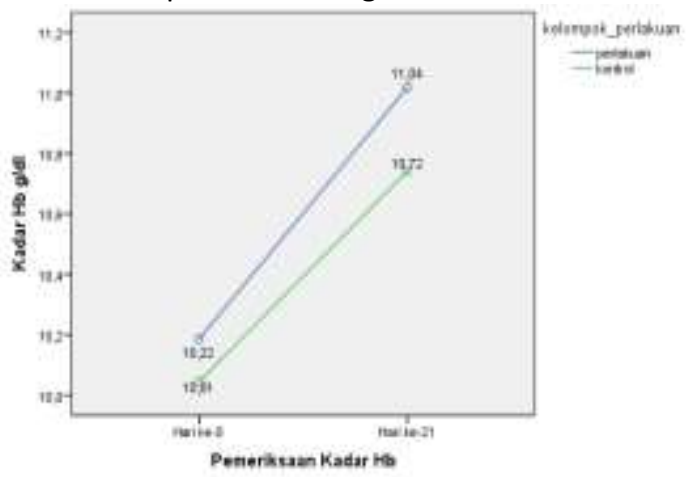

Gambar 1. Peningkatan Kadar Hemoglobin pada Kedua Kelompok Ibu Hamil Anemia Sebelum dan Setelah Perlakuan Selama 20 hari di Wilayah Kerja Puskesmas Lerep Kabupaten Semarang Tahun 2018

\section{PEMBAHASAN}

\section{Karakteristik Responden}

Hasil analisis pada tabel 1, didapatkan responden penelitian yang menunjukkan bahwa 90,0\% responden masuk dalam kategori usia reproduktif. Usia 20-35 tahun merupakan usia reproduktif yang ideal bagi wanita untuk hamil. Usia Ibu hamil akan berpengaruh terhadap gizi dan kondisi kesehatan ibu hamil sehingga juga dapat berpengaruh terhadap pertumbuhan dan perkembangan janin ${ }^{13}$. Penelitian ini sejalan dengan penelitian Merida (2014) yang berjudul "Efektifitas terapi kombinasi jus bayam dan tomat terhadap peningkatan kadar hemoglobin pada ibu hamil dengan anemia" di Puskesmas Sail Kecamatan Pekanbaru Riau yang menunjukkan bahwa usia terbanyak yang mengalami anemia pada kehamilan adalah rentang usia 20-35 tahun sebanyak $76,7 \%{ }^{14}$. Usia ibu merupakan salah satu faktor resiko yang berhubungan dengan kualitas kehamilan. Anemia pada ibu hamil tidak hanya bergantung pada usia ibu, namun banyak faktor lain yang juga mempengaruhinya ${ }^{15}$.

Penelitian ini menunjukkan bahwa $75,0 \%$ responden dengan pendidikan terakhir SMA mengalami anemia. Dari data diperoleh bahwa ibu yang berpendidikan tinggi lebih banyak menderita anemia, hal ini dikarenakan faktor ketidakperhatian ibu terhadap asupan makanannya. Hasil penelitian yang telah dilakukan di wilayah kerja Puskesmas Sail menunjukkan bahwa pendidikan terbanyak adalah pendidikan SMA sebanyak 43,3\%. Pendidikan adalah pembelajaran pengetahuan, keterampilan, dan kebiasaan sekelompok orang yang ditransfer dari satu generasi ke generasi berikutnya melalui pengajaran, pelatihan, atau penelitian. Pendidikan sering diajarkan di bawah bimbingan orang lain, tetapi juga memungkinkan secara otodidak ${ }^{16}$. Latar belakang pendidikan merupakan faktor yang mempengaruhi pola pikir seseorang. Latar belakang pendidikan akan membentuk cara berpikir seseorang termasuk membentuk kemampuan untuk memahami faktor-faktor yang berkaitan dengan penyakit dan menggunakan pengetahuan tersebut untuk menjaga kesehatan ${ }^{17}$.

Penelitian ini menunjukkan bahwa $55,0 \%$ responden tidak bekerja. Pekerjaan mempengaruhi status sosial ekonomi dan akan berpengaruh dalam mendapatkan pelayanan antenatal yang adekuat dan pemenuhan gizi. Ibu yang bekerja dapat menambah pendapatan rumah tangga sehingga dapat memperoleh pelayanan kesehatan selama hamil secara rutin 
dan cukup di dalam pemenuhan gizi sehingga kejadian anemia ibu hamil dapat teratasi dibandingkan jika hanya suami yang bekerja dalam memenuhi kebutuhan rumah tangga ${ }^{18}$. Hal ini sesuai dengan Sukarni \& Wahyu (2013) yang menyatakan baik status ekonomi maupun sosial sangat mempengaruhi seorang wanita dalam memilih makanannya. Semakin baik status ekonomi suatu keluarga maka semakin besar pula kemungkinan terpenuhinya kebutuhan zat gizi. Seorang ibu hamil dengan ekonomi yang tinggi kemungkinan besar gizi yang dibutuhkan tercukupi ditambah lagi adanya pemeriksaan membuat gizi ibu semakin terpantau ${ }^{19}$.

Penelitian ini menunjukkan bahwa $65,0 \%$ responden dengan usia kehamilan $13-$ 24 minggu (trimester II) memiliki status anemia, hasil ini sejalan dengan penelitian yang dilakukan oleh Lestari (2003) bahwa 54,4\% ibu hamil dengan umur kehamilan trimester II memiliki status anemia, dan hasil penelitian Yulaeva (2002) menunjukkan hasil yang sama, ada hubungan yang bermakna antara umur kehamilan dengan status anemia pada ibu hamil, sebanyak $32,8 \%$ ibu hamil dengan umur kehamilan trimester II dengan status anemia.

\section{Gambaran Asupan Zat Gizi}

Hasil analisis berdasarkan tabel 2, dapat dilihat gambaran asupan zat gizi yang dikonsumsi oleh responden meliputi asupan energi, protein, fe, vitamin $C$ dan vitamin $A$. Rerata asupan energi pada kelompok perlakuan dan kelompok kontrol masih tergolong dalam kategori kurang apabila dibandingkan dengan kebutuhan energi ibu hamil. Menurut Yogo Yuwono mengatakan ada hubungan yang bermakna antara tingkat kecukupan energi dengan kadar hemoglobin ibu hamil. Energi di dalam tubuh dihasilkan oleh zat gizi makro yang dikonversikan menjadi energi. Energi diperlukan juga untuk membantu proses gerakan otot saluran pencernaan, sehingga gerakan ini membantu saluran pencernaan tersebut dalam proses penyerapan zat besi pada usus. Umumnya orang yang kekurangan energi protein signifikan dengan kekurangan zat gizi lain seperti kurang zat besi yang akan menyebabkan anemia ${ }^{20}$.

Selain asupan energi yang kurang, asupan protein pada kelompok perlakuan dan kelompok kontrol juga masih tergolong dalam kategori kurang jika dibandingkan dengan kebutuhan energi ibu hamil. Protein berperan penting dalam transportasi zat besi di dalam tubuh.Absorpsi terutama terjadi di bagian atas usus halus (duodenum) dengan bantuan alat angkut protein khusus.Ada dua jenis alat pengangkut protein yang membantu penyerapan zat besi, yaitu transferin dan ferritin. Transferin mempunyai peranan sentral dalam metabolisme zat besi karena unsur protein ini mengangkut zat besi ke dalam sirkulasi yang memerlukan zat besi misalnya dari usus ke sumsum tulang dan organ lainnya untuk membentuk hemoglobin yang baru ${ }^{21}$. Asupan protein yang kurang akan mengakibatkan transportasi zat besi terhambat sehingga akan terjadi defisiensi zat besi yang ditandai dengan penurunan kadar hemoglobin dibawah nilai normal ${ }^{22}$.

\section{Kadar Hemoglobin Sebelum (Pretest) Dan Setelah Perlakuan (Posttest)}

Hasil analisis berdasarkan Tabel 3, menunjukkan bahwa rerata kadar hemoglobin ibu hamil anemia pada kelompok perlakuan saat pretest sebesar 10,22 g/dl dan rerata kadar hemoglobin saat posttest naik menjadi 11,04 g/dl, terjadi peningkatan rerata kadar hemoglobin saat pretest dan posttest sebesar $0.84 \mathrm{~g} / \mathrm{dl}$. Rerata kadar hemoglobin ibu hamil anemia pada kelompok kontrol saat pretest sebesar $10,01 \mathrm{~g} / \mathrm{dl}$ dan rerata kadar hemoglobin saat posttest naik menjadi $10,72 \mathrm{~g} / \mathrm{dl}$, terjadi peningkatan rerata kadar hemoblobin saat pretest dan posttest sebesar $0,71 \mathrm{~g} / \mathrm{dl}$.

4. Pengaruh Pemberian Sari Kacang Hijau Terhadap Kadar Hemoglobin Ibu Hamil Anemia

Hasil analisis ANOVA Repeated Measure pada Gambar 1, terlihat bahwa kedua kelompok yaitu kelompok perlakuan dan kelompok kontrol memiliki peningkatan kadar hemoglobin. Kedua kelompok perlakuan dan kontrol semuanya mengkonsumsi tablet tambah darah secara rutin setiap hari. Kelompok kontrol memiliki rerata peningkatan kadar hemoglobin sebesar $0,71 \mathrm{~g} / \mathrm{dl}$ sedangkan kelompok perlakuan yang diberikan sari kacang hijau memiliki rerata peningkatan kadar hemoglobin sebesar $0.84 \mathrm{~g} / \mathrm{dl}$. Sehingga terdapat peningkatan antar kedua kelompok sebelum dan sesudah intervensi. Peningkatan pada kelompok perlakuan lebih tinggi dibandingkan degan kelompok kontrol, walau peningkatan tersebut tidak signifikan dilihat dari nilai $p$ value $=0,452(p<0,05)$. Hasil tersebut 
sudah dikontrol dengan asupan energi, asupan protein, asupan zat besi, asupan vitamin $C$ dan asupan vitamin $\mathrm{A}$.

Pemerintah sudah berupaya untuk mengurangi kejadian anemia ibu hamil dengan cara memberikan suplementasi tablet $\mathrm{Fe}$ sebanyak 90 tablet pada ibu hamil. Ibu hamil dianjurkan mengkonsumsi suplemen tablet Fe setiap hari demi memenuhi kebutuhan zat besi yang semakin meningkat. Pada ibu hamil akan terjadi peningkatan volume darah yang signifikan. Pada awal kehamilan, volume plasma darah akan meningkat dengan cepat sebesar 40$45 \%$. Kenaikan eritrosit jauh lebih rendah daripada volume plasma, terjadi hemodilusi dan penurunan konsentrasi hemoglobin pada ibu hamil.Selain itu, pertumbuhan janin dan plasenta yang sangat pesat juga memerlukan banyak zat besi ${ }^{25}$. Ibu hamil yang mengkonsumsi tablet Fe 60 mg/hari dapat meningkatkan kadar hemoglobin sebesar $1 \mathrm{~g} \% /$ bulan $^{23}$.

Cara lain untuk menurunkan angka kejadian anemia pada ibu hamil tidak hanya diberikan suplemen tablet Fe, tetapi harus ditunjang dan dibantu dengan memberikan asupan makanan yang kaya akan zat besi.Salah satu jenis kacang-kacangan yang mengandung zat besi tinggi adalah kacang hijau.Kacang hijau mengandung zat-zat yang diperlukan untuk pembentukan sel darah sehingga dapat mengatasi efek penurunan hemoglobin.Jumlah kandungan zat besi pada kacang hijau sebanyak 6,7 mg per 100 gram kacang hijau ${ }^{12}$. Vitamin C dalam kacang hijau dapat meningkatkan absorbsi zat besi nonheme sampai empat kali lipat.Vitamin $C$ dengan zat besi mempunyai senyawa ascorbat besi kompleks yang larut dan mudah diabsorbsi. Peranan vitamin $\mathrm{C}$ dalam proses penyerapan zat besi yaitu dengan mereduksi besi ferri $\left(\mathrm{Fe}^{3+}\right)$ menjadi ferro $\left(\mathrm{Fe}^{2+}\right)$ dalam usus halus sehingga mudah diabsorbsi, proses reduksi tersebut akan menjadi semakin besar apabila $\mathrm{pH}$ di dalam lambung semakin meningkat sehingga dapat meningkatkan penyerapan zat besi hingga $30 \%$. Vitamin C menghambat pembentukan hemosiderin yang sukar dimobilisasi untuk membebaskan besi bila diperlukan ${ }^{19}$.

Kandungan asam amino pada kacang hijau cukup lengkap yang terdiri dari asam amino esensial yakni isoleusin, leusin, lisin, metionin, fenilalanin, treonin, valin, dan juga asam amino nonesensial yakni alanin, arginin, asam aspartat, asam glutamat, glisin, triptofan dan tirosin ${ }^{24}$. Kandungan protein, karbohidrat, dan lemak pada kacang hijau mendukung proses sintesis hemoglobin. Karbohidrat dan lemak membentuk suksinil-KoA yang selanjutnya bersama glisin akan membentuk protoporfirin melalui serangkaian proses porifirinogen. Protofirin yang terbentuk selanjutnya bersama molekul heme dan protein globin membentuk hemoglobin ${ }^{21}$. Kandungan glisin $0,9 \%$ dari $22 \%$ jumlah asam amino total pada kacang hijau, sehingga kacang hijau selain mampu membantu sintesis heme juga sebagai bahan pembentuk sintesis heme. Menurut Bovell-Benjamin (2000) menyatakan bahwa absorbsi besi dapat meningkat 4 kali lipat dengan pemberian glisin. Penelitian tersebut dengan menggunakan preparat iron bis-glycine yaitu senyawa besi-glisin kuat yang dapat menghasilkan konfigurasi cincin heterosiklik ganda. Bentuk ini dipercaya dapat melindungi besi dari faktor penghambat besi dan berbagai interaksi di usus halus.Glisin juga turut membentuk antioksidan glutation yang dapat mempertahankan besi dalam bentuk ferro, sehingga absorbsi besi dapat ditingkatkan.

Proses absorbsi besi dalam usus yaitu zat besi diserap di dalam duodenum dan jejunum bagian atas melalui proses yang kompleks. Besi yang terdapat di dalam bahan pangan baik dalam bentuk $\mathrm{Fe}^{3+}$ atau $\mathrm{Fe}^{2+}$ mulamula mengalami proses pencernaan. Di dalam lambung $\mathrm{Fe}^{3+}$ larut dalam asam lambung, kemudian diikat oleh gastroferin dan direduksi menjadi $\mathrm{Fe}^{2+}$ (Ferro) dengan adanya asam ascorbat (vitamin C). Didalam usus $\mathrm{Fe}^{2+}$ dioksidasi menjadi $\mathrm{Fe}^{3+}$, yang selanjutnya berikatan dengan apoferitin yang kemudian ditransformasi menjadi ferritin, membebaskan $\mathrm{Fe}^{2+}$ ke dalam plasma darah. Di dalam plasma, $\mathrm{Fe}^{2+}$ dioksidasi menjadi $\mathrm{Fe}^{3+}$ dan berikatan dengan transferitin.Transferitin mengangkut $\mathrm{Fe}^{2+}$ ke dalam sumsum tulang untuk bergabung membentuk hemoglobin.Transferitin mengangkut $\mathrm{Fe}^{2+}$ ke dalam tempat penyimpanan besi di dalam tubuh (hati, sumsum tulang, limpa, dan sistem retikuloendotelial) kemudian dioksidasi menjadi $\mathrm{Fe}^{3+} \cdot \mathrm{Fe}^{3+}$ ini bergabung dengan apoferitin membentuk ferritin yang kemudian akan disimpan ${ }^{19}$.

Kacang hijau juga mengandung vitamin A sebesar $7 \mathrm{mcg}$ dalam setengah cangkirnya.Kekurangan vitamin A dapat memperburuk anemia defisiensi besi. Vitamin A memiliki banyak peran di dalam tubuh, antara lain untuk pertumbuhan dan diferensiasi sel progenitoreritrosit, imunitas tubuh terhadap infeksi dan mobilisasi cadangan zat besi seluruh jaringan. Kacang hijau mengandung 20-25\% protein.Protein pada kacang hijau memiliki daya 
cerna sekitar 77\%.Daya cerna yang tidak terlalu tinggi tersebut disebabkan oleh adanya zat antigizi, seperti anti tripsin dan tanin (polifenol). Untuk meningkatkan daya cerna protein tersebut, kacang hijau harus diolah terlebih dahulu melalui proses pemasakan, seperti perebusan, pengukusan, dan sangrai ${ }^{25}$.

Penelitian tentang pemberian kacang hijau terhadap kadar hemoglobin pernah dilakukan oleh Stefani (2017) menunjukkan bahwa pemberian jus kacang hijau dapat meningkatkan kadar hemoglobin dan sel darah pada ibu hamil dengan anemia yang mendapatkan suplementasi tablet fe selama 2 minggu ${ }^{13}$. Penelitian ini sejalan dengan penelitian yang dilakukan oleh Dewi (2017) tentang pemberian tablet Fe dan sari kacang hijau terhadap kadar hemoglobin pada ibu hamil sebanyak 32 responden di masing-masing kelompok menunjukkan bahwa terdapat peningkatan sebesar 0,91 pada kelompok intervensi ${ }^{26}$.

\section{KESIMPULAN}

Pemberian sari kacang hijau pada ibu hamil selama 20 hari dapat meningkatkan kadar hemoglobin sebanyak $0.84 \mathrm{~g} / \mathrm{dl}$ meskipun secara statistik tidak signifikan.

\section{SARAN}

Bagi Ibu hamil disarankan untuk mengkonsumsi $100 \mathrm{~g}$ kacang hijau dalam sari kacang hijau sebanyak $250 \mathrm{ml}$ atau satu gelas perhari karena kandungan zat besi, protein, vitamin C dan vitamin A yang terkandung dalam kacang hijau bermanfaat untuk pembentukan zat besi dalam tubuh.

Bagi peneliti lain, hasil penelitian ini dapat dijadikan salah satu referensi kepustakaan penelitian selanjutnya dan untuk dapat melanjutkan penelitian yang lebih mendalam yang berkaitan dengan faktor-faktor yang mempengaruhi kejadian anemia lainnya seperti pendapatan, paritas, tingkat pengetahuan dan status gizi dengan mengambil sampel yang lebih banyak yaitu 40 orang pada kedua kelompok dan dalam jangka waktu yang lebih lama yaitu lebih dari 20 hari.

\section{DAFTAR PUSTAKA}

1. Kementerian Kesehatan R. Rencana dan Strategi Kesehatan. 2015;
2. Akhtar M, Hassan I. Severe Anaemia during Late Pregnancy. Case Rep Obstet Gynecol. 2012;2012:1-3.

3. WHO. 2012-2013. Dep Nutr Heal Dev Evid Program Guid. 2013;

4. Badan Penelitian dan Pengembangan Kesehatan. Riset Kesehatan Dasar (RISKESDAS) 2013. Lap Nas 2013. 2013;1-384.

5. Dinas Kesehatan Provinsi Jawa Tengah. Profil Kesehatan Provinsi Jawa Tengah. Dinas Kesehat Provinsi Jawa Teng. 2015;48-9.

6. Dinas Kesehatan Kabupaten Semarang. Profil Kesehatan Kabupaten Semarang. 2015.

7. Rangkuti FH. Gambaran Faktor-Faktor Kejadian Anemia Pada Ibu Hamil Di Puskesmas Lerep Kecamatan Ungaran Barat Kabupaten Semarang 1. 2017;

8. Manuaba IB. Pengantar Kuliah Obstetry. Jakarta: EGC; 2010.

9. Susanti, Kumala MT. Farmakologi Kebidanan, Aplikasi dalam praktik kebidanan. Trans Info Media (TIM); 2011.

10. Dheny Rohmatika, Supriyana Dr. Perbandingan Pengaruh Pemberian Ekstrak Bayam Hijau Dengan Preparat Fe Terhadap Perubahan Kadar Hemoglobin Ibu Hamil Pasien Puskesmas. 2016;

11. Arisman. Gizi Dalam Daur Kehidupan. Jakarta: Penerbit Buku Kedokteran EGC; 2010.

12. USDA Food Composition Database. National Nutrient Database for Standard Reference Release 28 slightly revised May, 2016 Full Report ( All Nutrients ). 2017;2016-9.

13. Anastasia S. Pengaruh Pemberian Jus Kacang Hijau Terhadap Profil Darah pada Ibu Hamil dengan anemia. 2017;

14. Merida N, Utomo W. Efektifitas terapi kombinasi jus bayam dan tomat terhadap peningkatan kadar hemoglobin pada ibu hamil dengan anemia 1. 2014;1-9.

15. Nasyidah. Hubungan anemia dan karakteristik ibu hamil di Puskesmas Alianyang Pontianak. 2011;

16. Kementerian Kesehatan RI. Ringkasan eksekutif. Data dan informasi kesehatan Indonesia. 2013;

17. Perry, Potter. Buku ajar fundamental keperawatan: Konsep, proses dan praktik. Jakarta: EGC; 2005.

18. Indonesia DKR. Pedoman Pemantauan Wilayah Setempat Kesehatan Ibu dan Anak (PWS-KIA). Jakarta; 2003.

19. Sukarni. Kehamilan, Persalinan, Dan Nifas. Yogyakarta: Nuha Medika; 2013.

20. Heny Y, Laksmi W, Ronny A. Hubungan Tingkat Kecukupan Energi, Protein, Besi, Vitamin C Dan Suplemen Tablet Besi Dengan Kadar 
Hemoglobin Ibu Hamil Trimester IIDan III (Di wilayah Kerja Puskesmas Purwanegara 2 Kabupaten Banjarnegara). 2017;5:675-82.

21. Murray. Biokimia Harper. Jakarta: EGC; 2003.

22. Almatsier S. Prinsip Dasar IImu Gizi. Jakarta: PT Gramedia Pustaka Utama; 2009.

23. Saifudin. Buku Acuan Nasional Pelayanan Kesehatan Maternal dan Neonatal. Jakarta: Yayasan Bina Pustaka; 2009.

24. Lambrides C, I DG. School of Land and Food Sciences, Plant Improvement Group, The University of Queensland, St Lucia, QLD 4072, Australia (chapter mungbeans). 2007;

25. Heltty. Pengaruh Jus Kacang Hijau Terhadap Kadar Hemoglobin Dan Jumlah Sel Darah Dalam Konteks Asuhan Keperawatan Pasien Kanker Dengan Kemoterapi Di Rsup Fatmawati Jakarta. 2008;

26. Retnorini DL, Widatiningsih S. Pengaruh Pemberian Tablet Fe Dan Sari Kacang Hijau. 2017;6(12):8-16. 